\title{
Testosterone therapy and cardiovascular events among men: a systematic review and meta-analysis of placebo-controlled randomized trials
}

\author{
Lin $\mathrm{Xu}^{1}$, Guy Freeman ${ }^{1}$, Benjamin J Cowling ${ }^{1}$ and C Mary Schooling ${ }^{1,2^{*}}$
}

\begin{abstract}
Background: Testosterone therapy is increasingly promoted. No randomized placebo-controlled trial has been implemented to assess the effect of testosterone therapy on cardiovascular events, although very high levels of androgens are thought to promote cardiovascular disease.

Methods: A systematic review and meta-analysis was conducted of placebo-controlled randomized trials of testosterone therapy among men lasting 12+ weeks reporting cardiovascular-related events. We searched PubMed through the end of 2012 using "("testosterone" or "androgen") and trial and ("random*")" with the selection limited to studies of men in English, supplemented by a bibliographic search of the World Health Organization trial registry. Two reviewers independently searched, selected and assessed study quality with differences resolved by consensus. Two statisticians independently abstracted and analyzed data, using random or fixed effects models, as appropriate, with inverse variance weighting.
\end{abstract}

Results: Of 1,882 studies identified 27 trials were eligible including 2,994, mainly older, men who experienced 180 cardiovascular-related events. Testosterone therapy increased the risk of a cardiovascular-related event (odds ratio (OR) 1.54, 95\% confidence interval (Cl) 1.09 to 2.18). The effect of testosterone therapy varied with source of funding ( $P$-value for interaction 0.03), but not with baseline testosterone level ( $P$-value for interaction 0.70). In trials not funded by the pharmaceutical industry the risk of a cardiovascular-related event on testosterone therapy was greater ( $\mathrm{OR} 2.06,95 \% \mathrm{Cl} 1.34$ to 3.17) than in pharmaceutical industry funded trials (OR $0.89,95 \% \mathrm{Cl} 0.50$ to 1.60).

Conclusions: The effects of testosterone on cardiovascular-related events varied with source of funding. Nevertheless, overall and particularly in trials not funded by the pharmaceutical industry, exogenous testosterone increased the risk of cardiovascular-related events, with corresponding implications for the use of testosterone therapy.

Keywords: Testosterone, Cardiovascular, Men, Trial

\section{Background}

In observational studies low serum testosterone is associated with cardiovascular disease [1,2]. Testosterone may protect or be a secondary risk marker of other processes [1-3]. On the precautionary principle, expert advice and reviews, largely based on observational evidence, warn that cardiovascular disease may be increased by androgen deprivation therapy [4] and low testosterone [5,6]. Awareness

\footnotetext{
* Correspondence: mschooli@hunter.cuny.edu

* Correspondence: mschooll@hunter.cuny.edu
'School of Public Health, Li Ka Shing Faculty of Medicine, The University of Hong Kong, 21 Sassoon Road, Pokfulam, Hong Kong, China

${ }^{2}$ CUNY School of Public Health at Hunter College, 2180 Third Avenue, New ${ }^{2}$ CUNY School of Public
York, NY 10035, USA
}

\section{Biomed Central}

(c) 2013 Xu et al.; licensee BioMed Central Ltd. This is an Open Access article distributed under the terms of the Creative Commons Attribution License (http://creativecommons.org/licenses/by/2.0), which permits unrestricted use, distribution, and reproduction in any medium, provided the original work is properly cited.
[7,8]. Testosterone use is increasing [9-11], possibly as self-medication in response to advertising.

In 2004 the Institute of Medicine (IOM) reviewed the evidence on testosterone therapy and concluded, largely based on placebo-controlled trials, that there is not clear evidence of benefit for any of the health outcomes examined' [12]. The IOM recommended small-scale trials to establish the efficacy of testosterone therapy where other treatments were not available [12]. To our knowledge, no trial has been designed to assess the effect of testosterone therapy on cardiovascular morbidity or mortality. Previous 
meta-analyses of randomized placebo-controlled trials found that testosterone therapy resulted in a non-significantly higher risk of cardiovascular events, based on adverse events, but only included trials through March 2005 [13,14]. A more recent meta-analysis included trials through August 2008 but only reported on three specific cardiovascular outcomes, that is, arrhythmia, coronary bypass surgery and myocardial infarction [15]. Given the widespread use of testosterone, the high prevalence of cardiovascular disease in older men and no comprehensive assessment of the effect of testosterone therapy on cardiovascular events, an up-to-date meta-analysis may help inform clinical practice. We carried out a meta-analysis of adverse events from randomized placebo-controlled trials to examine the overall risk of cardiovascular-related events associated with testosterone therapy.

\section{Methods}

This meta-analysis follows the Preferred Reporting Items for Systematic Reviews and Meta-Analyses (PRISMA) checklist [see Additional file 1] and a published protocol (CRD42011001815) [16]. Two reviewers (LX and CMS) independently searched for and selected trials, resolving any differences by consensus. Two statisticians (GF and $\mathrm{BJC})$ extracted information from the selected trials.

\section{Data sources and searches}

We (LX and CMS) systematically searched PubMed until 31st December 2012 using "("testosterone" or "androgen") and $($ random*) and trial" with the selection limited to studies in men in English, because a preliminary search only found studies in English. We (LX and CMS) searched the World Health Organization (WHO) International Clinical Trials Registry Platform for any trial using testosterone as an intervention. From this search, we (LX and CMS) discarded any studies both agreed were irrelevant based on title or abstract and read the remaining. We did a bibliographic search of the selected trials and relevant reviews.

\section{Study selection}

We included randomized placebo-controlled trials giving cardiovascular-related events by study arm, because a report may focus on a particular aspect of the trial $[17,18]$ and not report all events that have occurred [17-19]. We excluded trials that only gave treatment-related events in the testosterone arm because these might not include full reporting of events in the placebo arm. Initially, we intended to exclude trials that only reported withdrawals as potentially less comprehensive than reporting of adverse events $[18,19]$, however this turned out to be a very fine distinction, so we included any trial reporting cardiovascular-related events by study arm.
We included any randomized controlled trial (RCT) of testosterone, but not other androgens, compared with placebo, including a comparison against a background of other treatments, because men likely to be taking testosterone may also be in treatment for other conditions. We excluded trials of less than twelve weeks' duration to assess long-term rather than acute effects of testosterone therapy.

We checked for duplication based on overlapping authorship, study description, number of participants and participant characteristics. When duplication occurred we used the study with the most comprehensive description of adverse events.

\section{Outcome}

The primary outcome was composite cardiovascularrelated events; because we anticipated too few events for robust assessment by cardiovascular event type; and a system-wide composite outcome may be most suitable for adverse events [20]. Cardiovascular-related events were defined as anything reported as such by the authors, that is, events reported as cardiac disorders, cardiovascular complaints, cardiovascular events, vascular disorders, cardiac or cardiovascular, or where the event description fell within the International Statistical Classification of Disease (ICD) version 10 chapter IX (I00 to 199). Most trials only reported serious adverse events, but a few also reported a wider range of events, so we also examined the effect of testosterone therapy by seriousness. Seriousness was based on the US Department of Agriculture definition of serious adverse events and the type of cardiovascular event generally considered serious [21]. Serious cardiovascular events were defined as cardiovascular-related events which the authors described as serious adverse events or where the outcome was death, life-threatening, hospitalization, involved permanent damage or required medical/surgical intervention, or was one of the following types of cardiovascular event: myocardial infarction, unstable angina, coronary revascularization, coronary artery disease, arrhythmias, transient ischemic attacks, stroke or congestive heart failure but not deep vein thrombosis.

\section{Data extraction and quality assessment}

A statistician (GF) extracted the number of participants randomized and cardiovascular-related events by trial arm. Event classification was checked by a physician (LX). A second statistician (BJC) checked the information extracted. Where trials reported cardiovascular-related events without giving the study arm, we contacted the authors twice by email to ask for cardiovascular-related events by study arm.

The reviewers (LX and CMS) independently used an established tool to evaluate the quality of each trial [22], 
focusing on the quality of reporting of cardiovascularrelated adverse events. First, we reported whether cardiovascular-related events were individually listed in a table by study arm, because these are easier to identify unambiguously. Second, we reported whether the type and severity of cardiovascular-related events reported was either pre-specified or identified before the allocation was revealed, because issues have been expressed about the reporting of adverse events [23,24]. Cardiovascularrelated events vary in severity making the selection criteria and categorization crucial to an outcome assessed from adverse events.

\section{Sensitivity analysis}

We initially planned only to assess whether the effects of testosterone on cardiovascular-related events varied with average baseline testosterone, because we did not expect sufficient trials for sub-group analysis by type of testosterone product or by type of cardiovascular-related event. However, the reporting of adverse events may be open to interpretation [23], and may not be comprehensive [25]. Given potential lack of clarity as to the selection of the cardiovascular-related adverse events reported, we also examined whether the effect of testosterone therapy varied with funding source. Finally, we also considered cardiovascular-related death as an outcome.

\section{Data synthesis and analysis}

We used the number of participants randomized as the denominator and included all cardiovascular-related events from the start. We used funnel plots and 'trim and fill' to assess publication bias, that is, missing trials. We used $\mathrm{I}^{2}$ to assess heterogeneity between trials, using fixed effects models where there was low heterogeneity $\left(\mathrm{I}^{2}<30 \%\right)$, otherwise using random effects models. We obtained the pooled odds ratio, using the 'metabin' function of the 'meta' package in $\mathrm{R}$ 2.14.1 ( $\mathrm{R}$ Development Core Team, Vienna, Austria). We used meta-analysis regression, with inverse variance weighting, to assess whether the effects of testosterone therapy varied with baseline testosterone or funding

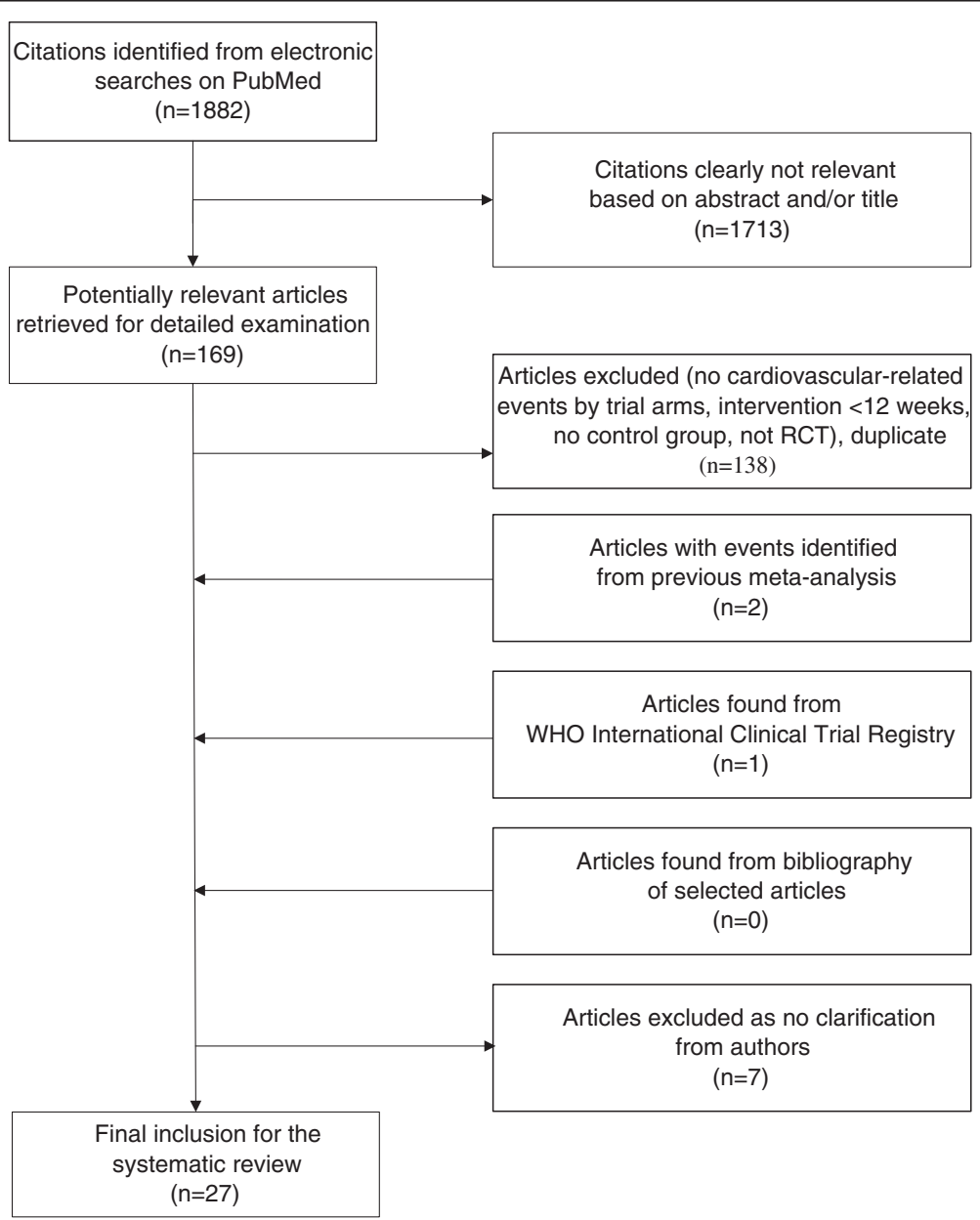

Figure 1 Selection process for the placebo-controlled randomized trials of the effects of testosterone therapy on cardiovascular-related events. 
source, using the 'rma' function of the 'metafor' package in $R$ 2.14.1. Initial analysis showed the pooled odds ratio was similar using a Peto or a Mantel-Haenszel estimate; we used inverse variance weighting for consistency with the meta-regression.

This study is an analysis of published data, which does not require ethics committee approval.

\section{Results}

The initial search yielded 1,882 papers, of which 169 were selected for full text scrutiny. Of these 169 papers, 31 concerned different placebo-controlled randomized trials among men of testosterone therapy of $12+$ weeks reporting cardiovascular-related events by study arm. We found one additional recent trial from the WHO International Clinical Trials Registry Platform [26]. We did not find any additional such trials from a bibliographic search of these 32 papers or from eight reviews [27-34]. Two additional trials $[35,36]$ selected for full text scrutiny had cardiovascular-related events shown in a plot from one previous meta-analysis [13], but not the other metaanalyses [14,15] or in the relevant publications [35-37]. The search did not find one small non-randomized trial [38] included in two previous meta-analyses [13,15]. The search found one additional trial [39] potentially relevant to the earlier meta-analyses [13,14], two additional trials $[40,41]$ potentially relevant to the most recent metaanalysis [15] and 11 subsequent trials. We sought clarification concerning events by study arm for 10 trials as set out in Additional file 2. Six authors never responded $[37,40,42-45]$, three responded but did not provide any relevant information $[36,46,47]$ and one provided information [48]. We included this later trial [48], one of the others that gave cardiovascular deaths, but not other cardiovascular-related events, by study arm [46] and one that gave vascular events, but not all cardiovascularrelated events by study arm [44]. Figure 1 shows the search strategy resulting in 27 placebo-controlled randomized trials.

Table 1 shows the 27 trials over 25 years of 2,994 mostly middle-aged or older men (1,733 testosterone and 1,261 placebo) with low testosterone and/or chronic diseases, who experienced 180 cardiovascular-related events. Most of the trials were in Western settings. Thirteen trials were supported by the pharmaceutical industry. Two trials were stopped early $[49,50]$, one because of adverse events among the men allocated to testosterone [50] and one because it would not be feasible to demonstrate - in the foreseeable future - a beneficial effect of testosterone [on mortality] by continuing the study' [49].

\section{Quality assessment}

The quality assessment (see Additional file 3) shows that two trials provided a table with a comprehensive list of cardiovascular-related events by study arm and eight trials provided a summary table of cardiovascular-related events by study arm. For 17 trials cardiovascular-related events were surmised from withdrawals and/or adverse events as given in Additional file 4, including one where the cardiovascular-related events were surmised from a $P$ value [65]. The type and severity of adverse events to be reported was pre-specified in one trial [61]. In the two trials terminated early the adverse events motivated termination and were identified before treatment allocation was known [49,50]. Otherwise it was sometimes unclear whether the definition or classification was made by masked assessors.

\section{Data synthesis}

The funnel plot (Figure 2) shows several small studies (on the left hand side) where testosterone reduced cardiovascular-related events, however, there were no similar small studies where testosterone increased cardiovascular-related events. The forest plot (Figure 3) shows that the trials were homogeneous $\left(\mathrm{I}^{2}=7.8 \%\right)$. Testosterone increased the risk of a cardiovascularrelated event in a fixed effect model, odds ratio (OR) 1.54, 95\% confidence interval (CI) 1.09 to 2.18. Trim and fill revised the OR to 1.69 (95\% CI 1.21 to 2.38). When the analysis was restricted to serious events, whose categorization is shown in Additional file 4, the estimate was very similar (OR 1.61 (95\% CI 1.01 to $2.56)$ ) and was revised to 2.01 (95\% CI 1.30 to 3.14 ) by trim and fill.

\section{Sensitivity analysis}

The cardiovascular-related event rate was lower in trials funded by the pharmaceutical industry $(4 \%(66 / 1,651))$ than in other trials $(8 \%(114 / 1,343))$. In a meta-regression model, risk of cardiovascular-related events on testosterone therapy varied with the source of funding ( $P$-value for interaction 0.03 ) but not with baseline testosterone $(P$-value for interaction 0.70$)$. In trials funded by the pharmaceutical industry testosterone had no effect on cardiovascular-related events, but in the other trials testosterone therapy substantially increased the risk of a cardiovascular-related event (Figure 4). Finally, 33 cardiovascular-related deaths were identified (22 testosterone arm and 11 placebo arm), for which the odds ratio was similar 1.42 (95\% CI 0.70 to 2.89 ) to the estimate for all cardiovascular-related events, and was revised to 1.57 (95\% CI 0.78 to 3.13 ) by trim and fill.

\section{Discussion}

This updated meta-analysis of placebo-controlled randomized trials, with a much larger number of participants than previous meta-analyses [13-15], adds to the previous findings by showing that testosterone therapy 


\begin{tabular}{|c|c|c|c|c|c|c|c|c|c|}
\hline \multirow{2}{*}{$\begin{array}{l}\text { Author and publication } \\
\text { year }\end{array}$} & \multicolumn{4}{|c|}{ Study } & \multicolumn{4}{|c|}{ Participants } & \multirow[t]{2}{*}{ Industry funding } \\
\hline & Setting & Duration & Dose & $\begin{array}{l}\text { Cardiovascular-related } \\
\text { events based on }\end{array}$ & $\begin{array}{l}\text { Age } \\
\text { range }\end{array}$ & Number & Health status & $\begin{array}{l}\text { Initial T } \\
\text { (nmol/L) }\end{array}$ & \\
\hline $\begin{array}{l}\text { Copenhagen Study } \\
\text { Group [49] } 1986\end{array}$ & Denmark & $\begin{array}{l}\text { About } 16 \\
\text { months }^{\mathrm{a}}\end{array}$ & 200 mg/8 h micronized T, PO & Deaths & 24 to 79 & 221 & alcoholic cirrhosis & about 20 & None given \\
\hline Marin [39] 1993 & Denmark & 9 months & T gel 125 mg/day & Withdrawals & 40 to 65 & 21 & Obese, low $T$ & 15.3 & $\begin{array}{l}\text { Funded by Besins } \\
\text { Iscovesco }\end{array}$ \\
\hline Hall [51] 1996 & UK & 9 months & $\begin{array}{l}\text { T enanthate } 250 \text { mg /month, } \\
\text { IM }\end{array}$ & Withdrawals & 34 to 79 & 35 & $\begin{array}{l}\text { Rheumatoid } \\
\text { arthritis }\end{array}$ & 16.1 & $\begin{array}{l}\text { Funded by Schering } \\
\text { Healthcare }\end{array}$ \\
\hline Sih [52] 1997 & US & 12 weeks & $\begin{array}{l}\text { T cypionate IM every } 14 \text { to } \\
17 \text { days }\end{array}$ & Withdrawals & 51 to 79 & 32 & $\mathrm{~T}<60 \mathrm{ng} / \mathrm{dl}$ & 9.2 & None given \\
\hline English [53] 2000 & UK & 12 weeks & Transdermal T 5 mg/day & Withdrawals and safety data & Mean 62 & 50 & $\begin{array}{l}\text { Coronary artery } \\
\text { disease }\end{array}$ & 12.9 & $\begin{array}{l}\text { Patches given by } \\
\text { Smith Kline Beecham }\end{array}$ \\
\hline Snyder [19] 2001 & US & 36 months & Transdermal T 6 mg/day & $\begin{array}{l}\text { Clinically apparent from } \\
\text { hospital records }\end{array}$ & $65+$ & 108 & $\begin{array}{l}\text { Men with T one } \\
\mathrm{SD}<475 \mathrm{ng} / \mathrm{dl}\end{array}$ & 12.7 & $\begin{array}{l}\text { Patches given by } \\
\text { ALZA Corporation }\end{array}$ \\
\hline Amory [54] 2004 & US & 36 months & $\begin{array}{l}\text { T enanthate } 200 \text { mg/2 weeks, } \\
\text { IM }\end{array}$ & $\begin{array}{l}\text { Serious adverse } \\
\text { cardiovascular events }\end{array}$ & 65 to 83 & 48 & $\Pi<350 \mathrm{ng} / \mathrm{dl}$ & 10 & None given \\
\hline Kenny [55] 2004 & US & 12 weeks & $\begin{array}{l}\text { T enanthate } 200 \mathrm{mg} / 3 \text { weeks, } \\
\text { IM }\end{array}$ & General description & 73 to 87 & 11 & $\begin{array}{l}\text { Cognitive decline, } \\
\text { bioavailable T } \\
<128 \mathrm{ng} / \mathrm{dl}\end{array}$ & 14.1 & None \\
\hline Svartberg [56] 2004 & Norway & 26 weeks & $\begin{array}{l}\text { T enanthate } 250 \text { mg/month, } \\
\text { IM }\end{array}$ & General description & Mean 66 & 29 & COPD & 21.1 & None \\
\hline $\begin{array}{l}\text { Brockenbrough [57] } \\
2006\end{array}$ & US & 6 months & Transdermal T gel $10 \mathrm{~g} /$ day & $\begin{array}{l}\text { Side effects and adverse } \\
\text { events }\end{array}$ & Mean 56 & 40 & $\begin{array}{l}\text { Dialysis and TT } \\
<300 \mathrm{ng} / \mathrm{dl}\end{array}$ & 7.3 & $\begin{array}{l}\text { Supported by } \\
\text { Auxilium } \\
\text { Pharmaceuticals }\end{array}$ \\
\hline Malkin [58] 2006 & UK & 12 months & Transdermal T patch 5 mg/day & Serious adverse events & Mean 64 & 76 & Heart failure & 13.0 & $\begin{array}{l}\text { Medication given by } \\
\text { Watson } \\
\text { Pharmaceuticals }\end{array}$ \\
\hline Merza [59] 2006 & UK & 6 months & Transdermal T patch 5 mg/day & Withdrawals & $40+$ & 39 & $\Pi<10 \mathrm{nmol} / \mathrm{L}$ & 8.0 & $\begin{array}{l}\text { Supported by Ferring } \\
\text { Pharmaceuticals Ltd }\end{array}$ \\
\hline Nair [60] 2006 & US & 24 months & Transdermal T patch 5 mg/day & Adverse events & $60+$ & 62 & $\begin{array}{l}\text { DHEA }<1.57 \mu \mathrm{g} / \mathrm{ml} \text {, } \\
\text { bioavailable T } \\
<103 \mathrm{ng} / \mathrm{dl}\end{array}$ & 13.7 & $\begin{array}{l}\text { Supported by The } \\
\text { Endocrine Society }\end{array}$ \\
\hline $\begin{array}{l}\text { Emmelot-Vonk [61] } \\
2008\end{array}$ & Netherlands & 6 months & TU 160 mg/day, PO & Adverse events & 60 to 80 & 237 & $\Pi<13.7 \mathrm{nmol} / \mathrm{L}$ & 10.7 & $\begin{array}{l}\text { Medication given by } \\
\text { Organon NV }\end{array}$ \\
\hline Svartberg [41] 2008 & Norway & 52 weeks & $\begin{array}{l}\text { TU } 1000 \mathrm{mg}, \mathrm{Ml} \text { at } 0,6,16,28 \\
\text { and } 40 \text { weeks }\end{array}$ & Deaths & 60 to 80 & 38 & $\Pi \leq 11.0 \mathrm{nmol} / \mathrm{L}$ & 8.3 & $\begin{array}{l}\text { Grant from Bayer } \\
\text { Schering Pharma AG }\end{array}$ \\
\hline Caminiti [62] 2009 & Italy & 12 weeks & $\begin{array}{l}\text { TU } 1000 \mathrm{mg} \mathrm{Ml} \text { for } 0,6 \text { and } \\
12 \text { weeks }\end{array}$ & General description of events & 66 to 76 & 70 & Heart failure & 7.0 & None given \\
\hline Chapman [48] 2009 & Australia & 1 year & TU 80 mg orally twice a day & Hospitalizations & $65+$ & 23 & Undernourished & 18.8 & $\begin{array}{l}\text { Organon provided } \\
\text { funding }\end{array}$ \\
\hline
\end{tabular}


Table 1 Characteristics of placebo-controlled randomized trials giving the effects of testosterone therapy on cardiovascular-related events among men (Continued)

\begin{tabular}{|c|c|c|c|c|c|c|c|c|c|}
\hline Legros [46] 2009 & Europe & 1 year & $\begin{array}{l}\text { TU 80, } 160 \text { and } 240 \text { mg orally } \\
\text { per day }\end{array}$ & Safety assessments & $50+$ & 316 & $\begin{array}{l}\text { Free } T<0.26 \mathrm{nmol} / \\
\mathrm{L}\end{array}$ & 12.8 & $\begin{array}{l}\text { Funded by Schering } \\
\text { Plough }\end{array}$ \\
\hline Aversa [63] 2010 & Italy & 24 months & TU 1,000 mg (every 12 weeks) & Safety aspects & 45 to 65 & 50 & $\begin{array}{l}\text { MS and/or T2DM } \\
\pi<3.0 \mathrm{ng} / \mathrm{ml}\end{array}$ & 8.5 & None given \\
\hline Basaria [50] 2010 & US & $\begin{array}{l}\text { About } 6 \\
\text { months }\end{array}$ & Transdermal T gel 100 mg/day & Cardiovascular-related events & $65+$ & 209 & $\begin{array}{l}\text { Frial, } \Pi 100 \text { to } \\
350 \mathrm{ng} / \mathrm{dl}\end{array}$ & 8.4 & $\begin{array}{l}\text { Medication given by } \\
\text { Auxilium } \\
\text { Pharmaceuticals }\end{array}$ \\
\hline $\begin{array}{l}\text { Srinivas-Shankar [64] } \\
2010\end{array}$ & US & 6 months & Transdermal T gel 50 mg/day & $\begin{array}{l}\text { Serious adverse events and } \\
\text { withdrawals }\end{array}$ & $65+$ & 274 & $\begin{array}{l}T T \leq 12 \mathrm{nmol} / \mathrm{L} \\
(345 \mathrm{ng} / \mathrm{dl})\end{array}$ & 11.0 & $\begin{array}{l}\text { Supported by Bayer } \\
\text { Schering Pharma }\end{array}$ \\
\hline Jones [65] 2011 & Europe & 12 months & T gel 60 mg/day & Cardiovascular events & 37 to 88 & 220 & $\begin{array}{l}\text { Hypogonadal with } \\
\text { type } 2 \text { diabetes } \\
\text { and/or MetS, }\end{array}$ & 9.4 & $\begin{array}{l}\text { Supported by } \\
\text { ProStrakan }\end{array}$ \\
\hline Ho 2011 [66] & Malaysia & 1 year & $\begin{array}{l}\text { TU } 1000 \mathrm{mg} \mathrm{Ml} \mathrm{for} 0,6,18,30 \\
\text { and } 42 \text { weeks }\end{array}$ & Withdrawals & $40+$ & 120 & $\mathrm{~T}<12 \mathrm{nmol} / \mathrm{L}$ & 9.0 & $\begin{array}{l}\text { Supported by Bayer } \\
\text { Schering Pharma }\end{array}$ \\
\hline Kaufman [44] 2011 & US & 182 days & 1.62\% T gel 2.5 mg/day & Safety aspects & 45 to 64 & 274 & $\begin{array}{l}\text { Hypogonadal, } \\
\mathrm{T}<300 \mathrm{ng} / \mathrm{dl}\end{array}$ & 9.8 & Funded by Abbott. \\
\hline Kalinchenko [67] 2010 & Russia & 30 weeks & $\begin{array}{l}\text { TU } 1,000 \mathrm{mg} \text { Ml for } 0,6,18 \\
\text { and } 30 \text { weeks }\end{array}$ & Withdrawal & 35 to 70 & 184 & $\mathrm{~T}<350 \mathrm{ng} / \mathrm{dl}$ & 7.0 & $\begin{array}{l}\text { Supported by Bayer } \\
\text { Schering Pharma }\end{array}$ \\
\hline Hoyos [68] 2012 & Australia & 18 weeks & $\begin{array}{l}\text { TU } 1000 \mathrm{mg} \mathrm{Ml} \text { at 0, } 6 \text { and } \\
12 \text { weeks }\end{array}$ & Adverse events & $\begin{array}{l}18+ \\
\text { mean } 49\end{array}$ & 67 & $\begin{array}{l}\text { Obese men with } \\
\text { obstructive sleep } \\
\text { apnea }\end{array}$ & 13.3 & $\begin{array}{l}\text { Supported by Bayer } \\
\text { Schering Pharma }\end{array}$ \\
\hline Spitzer [26] 2012 & US & 14 weeks & $1 \%$ T gel 10 g/day & Adverse events & 40 to 70 & 140 & $\begin{array}{l}\text { Erectile } \\
\text { dysfunction low } T \\
\text { and a sexual } \\
\text { partner }\end{array}$ & 12.3 & none \\
\hline
\end{tabular}




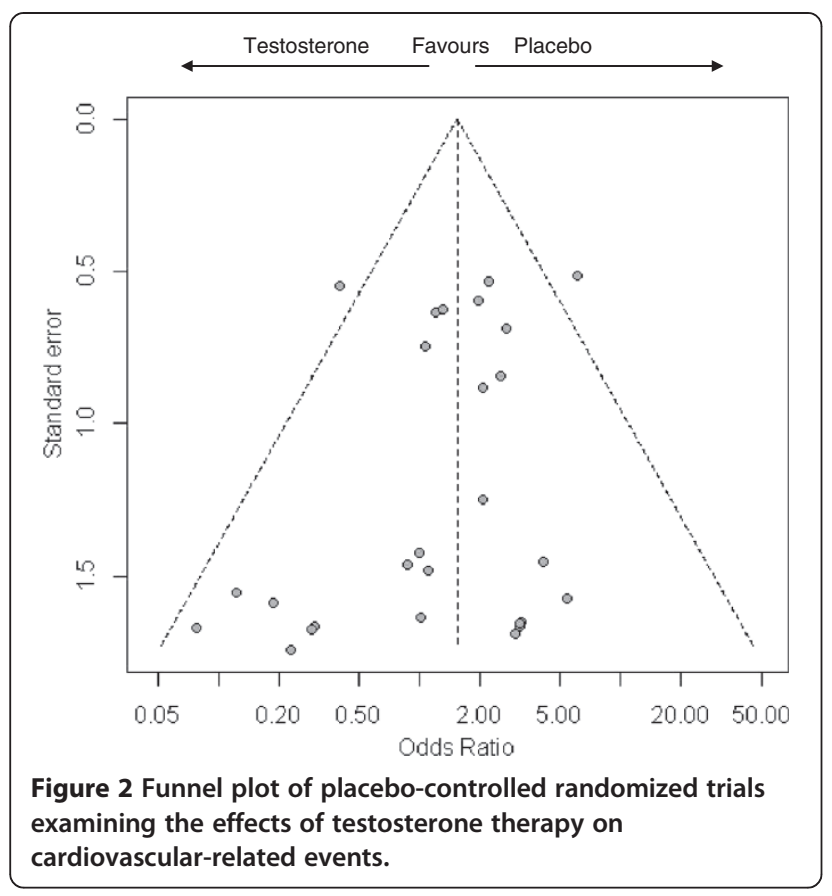

increases cardiovascular-related events among men. The risk of testosterone therapy was particularly marked in trials not funded by the pharmaceutical industry. The risks of cardiovascular-related events were similar by baseline testosterone.

Several possible explanations exist for our findings. First, not all trials of testosterone therapy reported all cardiovascular-related events by study arm $[36,46]$.
Trials favoring testosterone may be unpublished. However, the funnel plot (Figure 2) and 'trim and fill' suggested trials favoring the placebo may be missing. Second, endogenous and exogenous testosterone may have different effects, with endogenous testosterone being protective, consistent with the observational evidence $[1,2]$ and with testosterone declining with age when cardiovascular disease increases with age. However, a recent Mendelian randomization study, using genetic variants as an instrumental variable for endogenous testosterone, did not corroborate protective effects of endogenous testosterone on cardiovascular disease risk factors [69]. Another possibility is that serum testosterone is not a good indicator of androgen activity [70], as has long been suggested [71] and recently substantiated by the effective use of anti-androgens in prostate cancer at castrate levels of serum testosterone [72,73]. Third, endogenous testosterone may be beneficial, but other metabolites of exogenous testosterone, raised by testosterone therapy, such as estrogens or dihydrotestosterone, could mediate cardiovascular-related events. Exogenous estrogens do not protect men against cardiovascular disease [74]. However, higher free testosterone rather than higher estradiol appeared to mediate the cardiovascular events in a recent trial of testosterone therapy [75]. Few trials have examined the effects of dihydrotestosterone administration and have usually focused on prostate rather than cardiovascular effects [76-78]. The interplay of testosterone and dihydrotestosterone is complex and challenging to disentangle in RCTs [79]. Nevertheless, exogenous testosterone lowers HDL-cholesterol [15] and raises hemoglobin, hematocrit

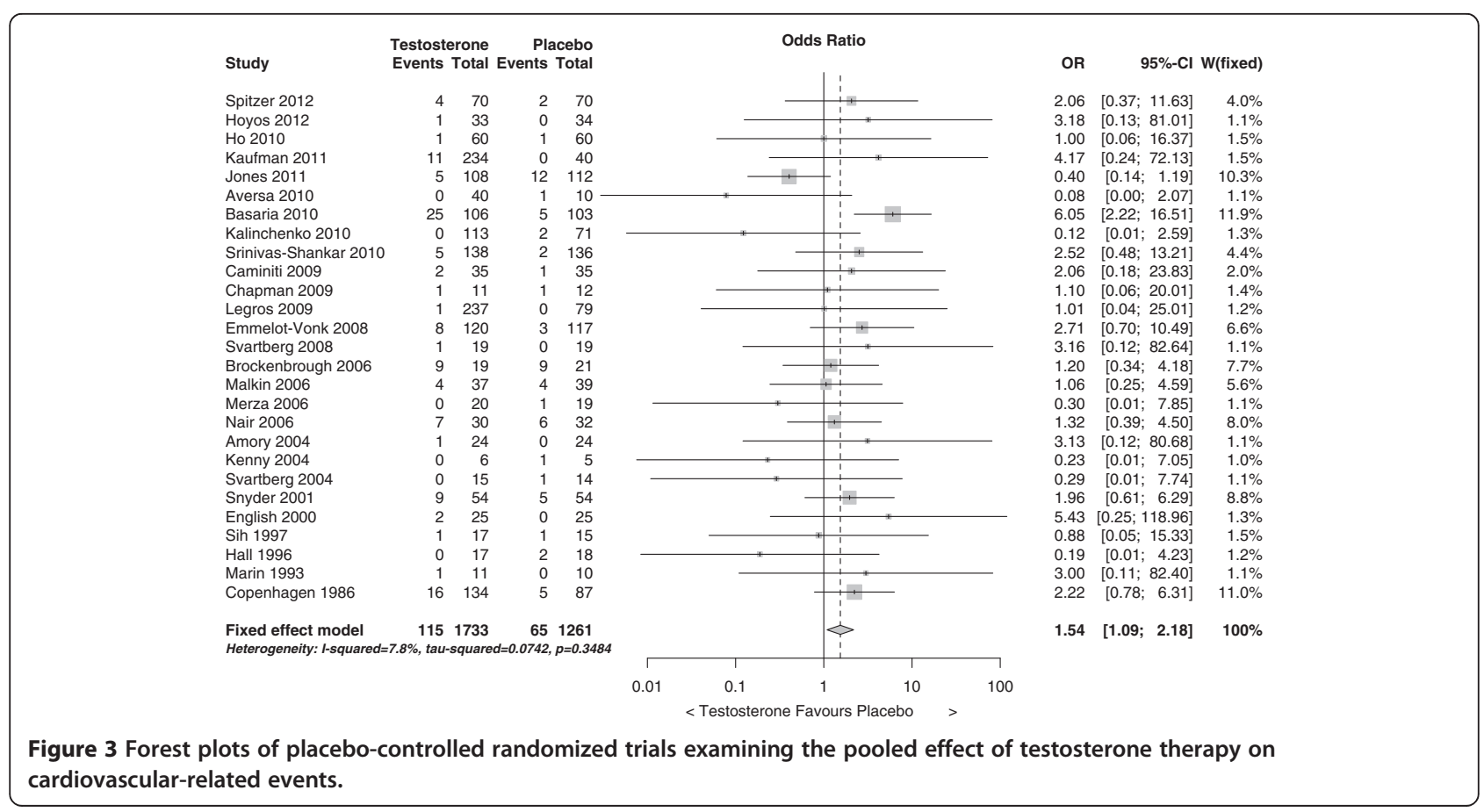


and thromboxane $[15,80]$, all of which might contribute to cardiovascular disease. Thromboxane promotes clotting and blood vessel constriction. Natural experiments suggest that lower lifetime endogenous androgens are associated with a relatively lower risk of death from ischemic heart disease, based on legally castrated men [81] and men with Klinefelter's syndrome [82]. Similarly, a metaanalysis of RCTs of androgen deprivation therapy found a non-significantly lower risk of cardiovascular mortality among men allocated to androgen deprivation [83], despite bias to the null by the competing risk of death from prostate cancer.

Our findings are consistent with the three previous metaanalyses [13-15], which all indicated a non-significantly higher risk of testosterone therapy for a composite cardiovascular outcome of the events considered, despite discrepancies in some studies $[13,14]$. This meta-analysis based on many more trials (27), many more men $(2,994)$ and correspondingly more events (180) produced a similar, but more precise estimate, with the confidence interval no longer including no effect. The difference between the estimates by funding source is consistent with other observations $[84,85]$ and could be due to different reporting of adverse events in industry funded trials. Differences by funding source could also be due to differences between trials. Industry funded trials reported fewer cardiovascularrelated events, which reduces power although it should not affect the direction of effect. Industry funded trials tended to be in younger men. It is possible, although unusual, for the effects of treatment to be 'crossed' by age [86].

From a clinical perspective the issue is ensuring that the benefits of testosterone therapy outweigh the potential risks. Almost a decade after the IOM's report [12] the efficacy of testosterone therapy for health outcomes where treatments are not already available remains uncertain. Testosterone compared to placebo could be beneficial for glucose metabolism [65], depression [87,88], sexual dysfunction [26,89], bone density [90] and HIV wasting syndrome [91,92], although whether testosterone is better than established treatments for these conditions has not been clearly established. Cardiovascular disease is common in typical users of testosterone therapy, that is, older men. The 10-year risk of a cardiovascular event for US men aged 65 to 69 years is about 28\% [93]. Assuming the increased risk of cardiovascular-related events seen here with testosterone therapy would give a number needed to 
harm of at most 90 per year of testosterone therapy. As such, further research might focus on obtaining evidence without interventions, for example by confirming that the observed negative associations of serum testosterone with specific cardiovascular diseases extends to other androgen biomarkers, such as androgen glucuronides [94], and to other study designs less open to biases, such as Mendelian randomization. Moreover, a gene in the steroidogenesis pathway (CYP17A1) is reliably associated with coronary artery disease [95]. Establishing if CYP17A1 acts, if at all, by raising or lowering androgens would also bring clarity. Finally, consideration could be given to whether further trials should be of agents that raise or lower testosterone.

\section{Strengths and limitations}

Despite providing a meta-analysis of all known placebocontrolled randomized trials, limitations exist. First, the reporting of adverse events may be open to conflicts of interest [24]. The funnel plot and analysis by funding source are consistent with that possibility. A very large market is at stake [9]. Second, in a trial of a therapy, such as testosterone, which may change how men feel or their sex drive, some accidental unmasking may have occurred. Few trials assessed or reported this possibility. Third, some men in the testosterone arm stopped treatment because of increased prostate specific antigen or polycythemia, which would bias towards the null. Fourth, RCTs are not always tagged as such and could be missed [96]. However, we searched broadly and found several potentially eligible trials that had not been included in previous meta-analyses. Fifth, our study cannot include on-going trials, such as the Testosterone Supplementation and Exercise in Elderly Men trial (NCT00112151) and The Testosterone Trial (NCT00799617). However, these trials are not designed to assess the effect of testosterone on cardiovascular events and will take time to complete. If new trials show testosterone therapy to be strongly protective against cardiovascular disease, it would be against the general run of evidence to date making interpretation uncertain because of heterogeneity [97]. Sixth, the abstractors were not blinded. Seventh, most trials only reported fairly serious cardiovascular-related events, but the severity varied between trials, although for RCTs the reporting of events should be comparable within trials, and the events reported are more or less severe symptoms of cardiovascular disease on the pathway to cardiovascular mortality. An analysis restricted to events which could be identified as serious gave a similar estimate, but was limited by relying on events the authors had chosen to describe in detail by study arm and was revised upwards by trim and fill. Arguably, the standard definitions of event seriousness, including hospitalization, do not apply to frail older men, because they may be particularly prone to hospitalization. On the other hand, frail older people may also be most affected by any decrement to their already poor health, so hospitalization may represent a particularly significant event. Notably, an estimate based solely on deaths also had a similar point estimate, although the confidence interval included no effect because of low power. Eighth, two larger trials were terminated early $[49,50]$ which reduces power and could affect the estimates. However, the terminations took place towards the end of the planned trials and did not specifically concern cardiovascular-related events. Nevertheless, early terminations may have slightly increased the estimate and widened the confidence intervals. However, the interpretation would, most likely, have been similar. Ninth, although meta-analyses are a mainstay of evidence-based medicine they may be less reliable than large RCTs. Metaanalysis may overstate the benefits of treatment [98] however, they are less prone to overstate the harms [98]. Subsequent large RCTs rarely reverse the direction of effect from meta-analysis [99]. Tenth, given the lack of detailed cardiovascular-event reporting secondary analysis by type of cardiovascular event was not possible. Such sub-group analysis would undoubtedly be etiologically valuable. However, from a public health perspective the issue is identifying side-effects, where a composite outcome relating to a particular system (here the cardiovascular system) has been recommended [20]. Finally, the difference observed by source of funding could just be chance variation; however, testosterone therapy increased the risk of cardiovascular-related events overall.

\section{Conclusions}

Appropriately prescribed testosterone is undoubtedly beneficial. However, caution needs to be exercised to ensure that the associated health benefits of testosterone therapy outweigh the potential increased risk of cardiovascularrelated events, particularly in older men where cardiovascular disease is common.

\section{Additional files}

\section{Additional file 1: PRISMA 2009 Checklist.}

Additional file 2: Trials where authors contacted for additional information and responses. [13,35-37,40,42-48,100].

Additional file 3: Quality assessment of the selected placebocontrolled RCTs of the effects of testosterone therapy on cardiovascular-related events (CRE) [19,26,39,41,44,46,48-68].

Additional file 4: Description of cardiovascular-related events in the selected placebo-controlled RCTs [19,26,39,41,44,46,48-67,101].

\section{Abbreviations}

Cl: confidence interval; CYP17A1: cytochrome P450 17A1; IOM: Institute of Medicine; ICD: International Statistical Classification of Disease; OR: odds ratio; PRISMA: Preferred Reporting Items for Systematic Reviews and Meta-Analyses; RCT: randomized controlled trial; WHO: World Health Organization. Systematic review reference number CRD42011001815. 


\section{Competing interests}

All authors declare: no support from any organization for the submitted work; BJC has received research funding from Medlmmune Inc., and consults for Crucell MV; no other relationships or activities exist that could appear to have influenced the submitted work.

\section{Authors' contributions}

LX carried out the systematic search and drafted the manuscript. GF and BJC did the data extraction and analysis; they also reviewed the manuscript critically. CMS originated the idea, carried out the systematic search and helped draft the manuscript. All authors had full access to all the data in the study and take responsibility for the integrity of the data and the accuracy of the data analysis. LX is the guarantor. All authors read and approved the final manuscript.

\section{Acknowledgements}

The authors thank Steffie Woolhandler, David Himmelstein and Heidi Jones for their support.

Received: 17 December 2012 Accepted: 15 March 2013 Published: 18 April 2013

\section{References}

1. Araujo AB, Dixon JM, Suarez EA, Murad MH, Guey LT, Wittert GA: Clinical review: endogenous testosterone and mortality in men: a systematic review and meta-analysis. J Clin Endocrinol Metab 2011, 96:3007-3019.

2. Ruige JB, Mahmoud AM, De Bacquer D, Kaufman JM: Endogenous testosterone and cardiovascular disease in healthy men: a meta-analysis. Heart 2011, 97:870-875.

3. Sartorius G, Spasevska S, Idan A, Turner L, Forbes E, Zamojska A, Allan CA, Ly LP, Conway AJ, McLachlan RI, Handelsman DJ: Serum testosterone, dihydrotestosterone and estradiol concentrations in older men selfreporting very good health: the healthy man study. Clin Endocrinol (Oxf) 2012, 77:755-763.

4. Levine GN, D'Amico AV, Berger P, Clark PE, Eckel RH, Keating NL, Milani RV, Sagalowsky Al, Smith MR, Zakai N: Androgen-deprivation therapy in prostate cancer and cardiovascular risk: a science advisory from the American Heart Association, American Cancer Society, and American Urological Association: endorsed by the American Society for Radiation Oncology. CA Cancer J Clin 2010, 60:194-201.

5. Jones TH: Testosterone deficiency: a risk factor for cardiovascular disease? Trends Endocrinol Metab 2010, 21:496-503.

6. Traish AM, Saad F, Feeley RJ, Guay A: The dark side of testosterone deficiency: III. Cardiovascular disease. J Androl 2009, 30:477-494.

7. Eggertson L: Brouhaha erupts over testosterone-testing advertising campaign. CMAJ 2011, 183:E1161-E1162.

8. Morgentaler A: Testosterone for Life. New York: McGraw-Hill; 2008.

9. Sexual dysfunction as the last bastion of urological drug commercialisation within the pharmaceutical industry. BJU Int 2011, 107:1845-1846.

10. Handelsmann DJ: Pharmacoepidemiology of testosterone prescribing in Australia, 1992-2010. Med J Aust 2012, 196:642-645.

11. Gan EH, Pattman S, Pearce S, Quinton R: Many men are receiving unnecessary testosterone prescriptions. BMJ 2012, 345:e5469.

12. Committee on Assessing the Need for Clinical Trials of Testosterone Replacement Therapy: TESTOSTERONE AND AGING Clinical Research Directions. Washington: The National Academies Press; 2004

13. Calof OM, Singh AB, Lee ML, Kenny AM, Urban RJ, Tenover JL, Bhasin S: Adverse events associated with testosterone replacement in middleaged and older men: a meta-analysis of randomized, placebo-controlled trials. J Gerontol A Biol Sci Med Sci 2005, 60:1451-1457.

14. Haddad RM, Kennedy CC, Caples SM, Tracz MJ, Bolona ER, Sideras K, Uraga MV, Erwin PJ, Montori VM: Testosterone and cardiovascular risk in men: a systematic review and meta-analysis of randomized placebo-controlled trials. Mayo Clin Proc 2007, 82:29-39.

15. Fernandez-Balsells MM, Murad MH, Lane M, Lampropulos JF, Albuquerque F, Mullan RJ, Agrwal N, Elamin MB, Gallegos-Orozco JF, Wang AT, Erwin PJ, Bhasin S, Montori VM: Clinical review 1: adverse effects of testosterone therapy in adult men: a systematic review and meta-analysis. J Clin Endocrinol Metab 2010, 95:2560-2575.
16. Schooling C, Xu L, Freeman G, Cowling B: Testosterone and cardiovasclar related events in men: a meta-analysis of randomized controlled trials. PROSPERO 2011:CRD42011001815 http://www.crd.york.ac.uk/PROSPERO/ display_record.asp?ID=CRD42011001815

17. Snyder PJ, Peachey H, Hannoush P, Berlin JA, Loh L, Lenrow DA, Holmes JH, Dlewati A, Santanna J, Rosen CJ, Strom BL: Effect of testosterone treatment on body composition and muscle strength in men over 65 years of age. J Clin Endocrinol Metab 1999, 84:2647-2653.

18. Snyder PJ, Peachey H, Hannoush P, Berlin JA, Loh L, Holmes JH, Dlewati A, Staley J, Santanna J, Kapoor SC, Attie MF, Haddad JG Jr, Strom BL: Effect of testosterone treatment on bone mineral density in men over 65 years of age. J Clin Endocrinol Metab 1999, 84:1966-1972.

19. Snyder PJ, Peachey H, Berlin JA, Rader D, Usher D, Loh L, Hannoush P, Dlewati A, Holmes JH, Santanna J, Strom BL: Effect of transdermal testosterone treatment on serum lipid and apolipoprotein levels in men more than 65 years of age. Am J Med 2001, 111:255-260.

20. Tugwell $P$, Judd MG, Fries JF, Singh G, Wells GA: Powering our way to the elusive side effect: a composite outcome 'basket' of predefined designated endpoints in each organ system should be included in all controlled trials. J Clin Epidemiol 2005, 58:785-790.

21. Singh S, Loke YK, Spangler JG, Furberg CD: Risk of serious adverse cardiovascular events associated with varenicline: a systematic review and meta-analysis. CMAJ 2011, 183:1359-1366.

22. Verhagen AP, de Vet HC, de Bie RA, Kessels AG, Boers M, Bouter LM, Knipschild PG: The Delphi list: a criteria list for quality assessment of randomized clinical trials for conducting systematic reviews developed by Delphi consensus. J Clin Epidemiol 1998, 51:1235-1241.

23. Doshi $P$, Jones $M$, Jefferson $T$ : Rethinking credible evidence synthesis. $B M J$ 2012, 344:d7898. doi:10.1136/bmj.d7898.:d7898.

24. Ioannidis JP: Adverse events in randomized trials: neglected, restricted, distorted, and silenced. Arch Intern Med 2009, 169:1737-1739.

25. Pitrou I, Boutron I, Ahmad N, Ravaud P: Reporting of safety results in published reports of randomized controlled trials. Arch Intern Med 2009, 169:1756-1761.

26. Spitzer M, Basaria S, Travison TG, Davda MN, Paley A, Cohen B, Mazer NA Knapp PE, Hanka S, Lakshman KM, Ulloor J, Zhang A, Orwoll K, Eder R, Collins L, Mohammed N, Rosen RC, DeRogatis L, Bhasin S: Effect of testosterone replacement on response to sildenafil citrate in men with erectile dysfunction: a parallel, randomized trial. Ann Intern Med 2012, 157:681-691.

27. Corona G, Rastrelli G, Monami M, Guay A, Buvat J, Sforza A, Forti G, Mannucci E, Maggi M: Hypogonadism as a risk factor for cardiovascular mortality in men: a meta-analytic study. Eur J Endocrinol 2011, 165:687-701.

28. Cattabiani C, Basaria S, Ceda GP, Luci M, Vignali A, Lauretani F, Valenti G, Volpi R, Maggio M: Relationship between testosterone deficiency and cardiovascular risk and mortality in adult men. J Endocrinol Invest 2012, 35:104-120.

29. Carson CC 3rd, Rosano G: Exogenous testosterone, cardiovascular events, and cardiovascular risk factors in elderly men: a review of trial data. J Sex Med 2012, 9:54-67.

30. Gullett NP, Hebbar G, Ziegler TR: Update on clinical trials of growth factors and anabolic steroids in cachexia and wasting. Am J Clin Nutr 2010, 91:1143S-1147S.

31. Bain J: Testosterone and the aging male: to treat or not to treat? Maturitas 2010, 66:16-22

32. McLaren D, Siemens DR, Izard J, Black A, Morales A: Clinical practice experience with testosterone treatment in men with testosterone deficiency syndrome. BJU Int 2008, 102:1142-1146.

33. Krause W, Mueller U, Mazur A: Testosterone supplementation in the aging male: which questions have been answered? Aging Male 2005, 8:31-38.

34. Kaufman JM, Vermeulen A: The decline of androgen levels in elderly men and its clinical and therapeutic implications. Endocr Rev 2005, 26:833-876.

35. Kenny AM, Prestwood KM, Gruman CA, Fabregas G, Biskup B, Mansoor G: Effects of transdermal testosterone on lipids and vascular reactivity in older men with low bioavailable testosterone levels. J Gerontol A Biol SCi Med Sci 2002, 57:M460-M465

36. Crawford BA, Liu PY, Kean MT, Bleasel JF, Handelsman DJ: Randomized placebo-controlled trial of androgen effects on muscle and bone in men requiring long-term systemic glucocorticoid treatment. J Clin Endocrinol Metab 2003, 88:3167-3176.

37. Kenny AM, Prestwood KM, Gruman CA, Marcello KM, Raisz LG: Effects of transdermal testosterone on bone and muscle in older men with low bioavailable testosterone levels. J Gerontol A Biol Sci Med Sci 2001, 56:M266-M272. 
38. Morley JE, Perry HM 3rd, Kaiser FE, Kraenzle D, Jensen J, Houston K, Mattammal M, Perry HM Jr: Effects of testosterone replacement therapy in old hypogonadal males: a preliminary study. J Am Geriatr Soc 1993, 41:149-152.

39. Marin P, Holmang S, Gustafsson C, Jonsson L, Kvist H, Elander A, Eldh J, Sjostrom L, Holm G, Bjorntorp P: Androgen treatment of abdominally obese men. Obes Res 1993, 1:245-251.

40. Sullivan DH, Roberson PK, Johnson LE, Bishara O, Evans WJ, Smith ES, Price JA: Effects of muscle strength training and testosterone in frail elderly males. Med Sci Sports Exerc 2005, 37:1664-1672.

41. Svartberg J, Agledahl I, Figenschau Y, Sildnes T, Waterloo K, Jorde R: Testosterone treatment in elderly men with subnormal testosterone levels improves body composition and BMD in the hip. Int J Impot Res 2008, 20:378-387.

42. Steidle C, Schwartz S, Jacoby K, Sebree T, Smith T, Bachand R: AA2500 testosterone gel normalizes androgen levels in aging males with improvements in body composition and sexual function. J Clin Endocrinol Metab 2003, 88:2673-2681.

43. Kenny AM, Kleppinger A, Annis K, Rathier M, Browner B, Judge JO, McGee $D$ : Effects of transdermal testosterone on bone and muscle in older men with low bioavailable testosterone levels, low bone mass, and physical frailty. J Am Geriatr Soc 2010, 58:1134-1143.

44. Kaufman JM, Miller MG, Garwin JL, Fitzpatrick S, McWhirter C, Brennan JJ: Efficacy and safety study of $1.62 \%$ testosterone gel for the treatment of hypogonadal men. J Sex Med 2011, 8:2079-2089.

45. Frederiksen L, Hojlund K, Hougaard DM, Brixen K, Andersen M: Testosterone therapy increased muscle mass and lipid oxidation in aging men. Age (Dordr) 2012, 34:145-156.

46. Legros JJ, Meuleman EJ, Elbers JM, Geurts TB, Kaspers MJ, Bouloux PM: Oral testosterone replacement in symptomatic late-onset hypogonadism: effects on rating scales and general safety in a randomized, placebocontrolled study. Eur J Endocrinol 2009, 160:821-831.

47. Pugh PJ, Jones RD, West JN, Jones TH, Channer KS: Testosterone treatment for men with chronic heart failure. Heart 2004, 90:446-447.

48. Chapman IM, Visvanathan R, Hammond AJ, Morley JE, Field JB, Tai K, Belobrajdic DP, Chen RY, Horowitz M: Effect of testosterone and a nutritional supplement, alone and in combination, on hospital admissions in undernourished older men and women. Am J Clin Nutr 2009, 89:880-889.

49. Testosterone treatment of men with alcoholic cirrhosis: a double-blind study: The Copenhagen Study Group for Liver Diseases. Hepatology 1986, 6:807-813.

50. Basaria S, Coviello AD, Travison TG, Storer TW, Farwell WR, Jette AM, Eder R, Tennstedt S, Ulloor J, Zhang A, Choong K, Lakshman KM, Mazer NA, Miciek R, Krasnoff J, Elmi A, Knapp PE, Brooks B, Appleman E, Aggarwal S, Bhasin G, Hede-Brierley L, Bhatia A, Collins L, LeBrasseur N, Fiore LD, Bhasin S: Adverse events associated with testosterone administration. N Engl J Med 2010, 363:109-122

51. Hall GM, Larbre JP, Spector TD, Perry LA, Da Silva JA: A randomized trial of testosterone therapy in males with rheumatoid arthritis. Br J Rheumatol 1996, 35:568-573.

52. Sih R, Morley JE, Kaiser FE, Perry HM 3rd, Patrick P, Ross C: Testosterone replacement in older hypogonadal men: a 12-month randomized controlled trial. J Clin Endocrinol Metab 1997, 82:1661-1667.

53. English KM, Steeds RP, Jones TH, Diver MJ, Channer KS: Low-dose transdermal testosterone therapy improves angina threshold in men with chronic stable angina: a randomized, double-blind, placebo-controlled study. Circulation 2000, 102:1906-1911.

54. Amory JK, Watts NB, Easley KA, Sutton PR, Anawalt BD, Matsumoto AM, Bremner WJ, Tenover JL: Exogenous testosterone or testosterone with finasteride increases bone mineral density in older men with low serum testosterone. J Clin Endocrinol Metab 2004, 89:503-510.

55. Kenny AM, Fabregas G, Song C, Biskup B, Bellantonio S: Effects of testosterone on behavior, depression, and cognitive function in older men with mild cognitive loss. J Gerontol A Biol Sci Med Sci 2004, 59:75-78.

56. Svartberg J, Aasebo U, Hjalmarsen A, Sundsfjord J, Jorde R: Testosterone treatment improves body composition and sexual function in men with COPD, in a 6-month randomized controlled trial. Respir Med 2004, 98:906-913.

57. Brockenbrough AT, Dittrich MO, Page ST, Smith T, Stivelman JC, Bremner WJ: Transdermal androgen therapy to augment EPO in the treatment of anemia of chronic renal disease. Am J Kidney Dis 2006, 47:251-262.
58. Malkin CJ, Pugh PJ, West JN, van Beek EJ, Jones TH, Channer KS: Testosterone therapy in men with moderate severity heart failure: a double-blind randomized placebo controlled trial. Eur Heart J 2006, 27:57-64.

59. Merza Z, Blumsohn A, Mah PM, Meads DM, McKenna SP, Wylie K, Eastell R, Wu F, Ross RJ: Double-blind placebo-controlled study of testosterone patch therapy on bone turnover in men with borderline hypogonadism. Int J Androl 2006, 29:381-391.

60. Nair KS, Rizza RA, O'Brien P, Dhatariya K, Short KR, Nehra A, Vittone JL, Klee GG, Basu A, Basu R, Cobelli C, Toffolo G, Dalla MC, Tindall DJ, Melton LJ 3rd, Smith GE, Khosla S, Jensen MD: DHEA in elderly women and DHEA or testosterone in elderly men. N Engl J Med 2006, 355:1647-1659.

61. Emmelot-Vonk MH, Verhaar HJ, Nakhai Pour HR, Aleman A, Lock TM, Bosch JL, Grobbee DE, van der Schouw YT: Effect of testosterone supplementation on functional mobility, cognition, and other parameters in older men: a randomized controlled trial. JAMA 2008, 299:39-52.

62. Caminiti G, Volterrani M, lellamo F, Marazzi G, Massaro R, Miceli M, Mamm C, Piepoli M, Fini M, Rosano GM: Effect of long-acting testosterone treatment on functional exercise capacity, skeletal muscle performance, insulin resistance, and baroreflex sensitivity in elderly patients with chronic heart failure a double-blind, placebo-controlled, randomized study. J Am Coll Cardiol 2009, 54:919-927.

63. Aversa A, Bruzziches R, Francomano D, Rosano G, Isidori AM, Lenzi A, Spera $\mathrm{G}$ : Effects of testosterone undecanoate on cardiovascular risk factors and atherosclerosis in middle-aged men with late-onset hypogonadism and metabolic syndrome: results from a 24-month, randomized, double-blind , placebo-controlled study. J Sex Med 2010, 7:3495-3503.

64. Srinivas-Shankar U, Roberts SA, Connolly MJ, O'Connell MD, Adams JE, Oldham JA, Wu FC: Effects of testosterone on muscle strength, physical function, body composition, and quality of life in intermediate-frail and frail elderly men: a randomized, double-blind, placebo-controlled study. J Clin Endocrinol Metab 2010, 95:639-650.

65. Jones TH, Arver S, Behre HM, Buvat J, Meuleman E, Moncada I, Morales AM, Volterrani M, Yellowlees A, Howell JD, Channer KS: Testosterone replacement in hypogonadal men with type 2 diabetes and/or metabolic syndrome (the TIMES2 study). Diabetes Care 2011, 34:828-837.

66. Ho CC, Tong SF, Low WY, Ng CJ, Khoo EM, Lee VK, Zainuddin ZM, Tan HM: A randomized, double-blind, placebo-controlled trial on the effect of long-acting testosterone treatment as assessed by the Aging Male Symptoms scale. BJU Int 2012, 110:260-265.

67. Kalinchenko SY, Tishova YA, Mskhalaya GJ, Gooren LJ, Giltay EJ, Saad F: Effects of testosterone supplementation on markers of the metabolic syndrome and inflammation in hypogonadal men with the metabolic syndrome: the double-blinded placebo-controlled Moscow study. Clin Endocrinol (Oxf) 2010, 73:602-612.

68. Hoyos CM, Yee BJ, Phillips CL, Machan EA, Grunstein RR, Liu PY: Body compositional and cardiometabolic effects of testosterone therapy in obese men with severe obstructive sleep apnoea: a randomised placebo-controlled trial. Eur J Endocrinol 2012, 167:531-541.

69. Haring $R$, Teumer A, Volker U, Dorr M, Nauck M, Biffar R, Volzke H, Baumeister SE, Wallaschofski H: Mendelian randomization suggests noncausal associations of testosterone with cardiometabolic risk factors and mortality. Andrology 2013, 1:17-23.

70. Labrie F, Cusan L, Gomez JL, Martel C, Berube R, Belanger P, Belanger A, Vandenput L, Mellstrom D, Ohlsson C: Comparable amounts of sex steroids are made outside the gonads in men and women: strong lesson for hormone therapy of prostate and breast cancer. J Steroid Biochem Mol Biol 2009, 113:52-56

71. Labrie F: Intracrinology. Mol Cell Endocrinol 1991, 78:C113-C118.

72. Fizazi K, Scher HI, Molina A, Logothetis CJ, Chi KN, Jones RJ, Staffurth JN, North S, Vogelzang NJ, Saad F, Mainwaring P, Harland S, Goodman OB Jr, Sternberg CN, Li JH, Kheoh T, Haqq CM, de Bono JS: Abiraterone acetate for treatment of metastatic castration-resistant prostate cancer: final overall survival analysis of the COU-AA-301 randomised, double-blind, placebo-controlled phase 3 study. Lancet Oncol 2012, 13:983-992.

73. Scher HI, Fizazi K, Saad F, Taplin ME, Sternberg CN, Miller K, De WR, Mulders P, Chi KN, Shore ND, Armstrong AJ, Flaig TW, Flechon A, Mainwaring P, Fleming M, Hainsworth JD, Hirmand M, Selby B, Seely L, de Bono JS: Increased survival with enzalutamide in prostate cancer after chemotherapy. N Engl J Med 2012, 367:1187-1197. 
74. The Coronary Drug Project: Findings leading to discontinuation of the 2.5-mg day estrogen group. The Coronary Drug Project Research Group. JAMA 1973, 226:652-657.

75. Basaria S, Davda MN, Travison TG, Ulloor J, Singh R, Bhasin S: Risk factors associated with cardiovascular events during testosterone administration in older men with mobility limitation. J Gerontol A Biol Sci Med Sci 2013, 68:153-160

76. Idan A, Griffiths KA, Harwood DT, Seibel MJ, Turner L, Conway AJ, Handelsman DJ: Long-term effects of dihydrotestosterone treatment on prostate growth in healthy, middle-aged men without prostate disease: a randomized, placebo-controlled trial. Ann Intern Med 2010, 153:621-632.

77. Kunelius P, Lukkarinen O, Hannuksela ML, Itkonen O, Tapanainen JS: The effects of transdermal dihydrotestosterone in the aging male: a prospective, randomized, double blind study. J Clin Endocrinol Metab 2002, 87:1467-1472.

78. Ly LP, Jimenez M, Zhuang TN, Celermajer DS, Conway AJ, Handelsman DJ: A double-blind, placebo-controlled, randomized clinical trial of transdermal dihydrotestosterone gel on muscular strength, mobility, and quality of life in older men with partial androgen deficiency. J Clin Endocrinol Metab 2001, 86:4078-4088.

79. Bhasin S, Travison TG, Storer TW, Lakshman K, Kaushik M, Mazer NA, Ngyuen AH, Davda MN, Jara H, Aakil A, Anderson S, Knapp PE, Hanka S, Mohammed N, Daou P, Miciek R, Ulloor J, Zhang A, Brooks B, Orwoll K, Hede-Brierley L, Eder R, Elmi A, Bhasin G, Collins L, Singh R, Basaria S: Effect of testosterone supplementation with and without a dual 5alpha-reductase inhibitor on fat-free mass in men with suppressed testosterone production: a randomized controlled trial. JAMA 2012, 307:931-939.

80. Ajayi AA, Mathur R, Halushka PV: Testosterone increases human platelet thromboxane $\mathrm{A} 2$ receptor density and aggregation responses. Circulation 1995, 91:2742-2747.

81. Eyben FE, Graugaard C, Vaeth M: All-cause mortality and mortality of myocardial infarction for 989 legally castrated men. Eur J Epidemio/ 2005, 20:863-869.

82. Swerdlow AJ, Higgins CD, Schoemaker MJ, Wright AF, Jacobs PA: Mortality in patients with Klinefelter syndrome in Britain: a cohort study. J Clin Endocrinol Metab 2005, 90:6516-6522.

83. Nguyen PL, Je Y, Schutz FA, Hoffman KE, Hu JC, Parekh A, Beckman JA, Choueiri TK: Association of androgen deprivation therapy with cardiovascular death in patients with prostate cancer: a meta-analysis of randomized trials. JAMA 2011, 306:2359-2366.

84. Bhandari M, Busse JW, Jackowski D, Montori VM, Schunemann H, Sprague S, Mears D, Schemitsch EH, Heels-Ansdell D, Devereaux PJ: Association between industry funding and statistically significant pro-industry findings in medical and surgical randomized trials. CMAJ 2004, 170:477-480.

85. Gluud LL: Bias in clinical intervention research. Am J Epidemiol 2006, 163:493-501.

86. Petitti D: Commentary: hormone replacement therapy and coronary heart disease: four lessons. Int J Epidemiol 2004, 33:461-463.

87. Zarrouf FA, Artz S, Griffith J, Sirbu C, Kommor M: Testosterone and depression: systematic review and meta-analysis. J Psychiatr Pract 2009, 15:289-305.

88. Shamlian NT, Cole MG: Androgen treatment of depressive symptoms in older men: a systematic review of feasibility and effectiveness. Can J Psychiatry 2006, 51:295-299.

89. Bolona ER, Uraga MV, Haddad RM, Tracz MJ, Sideras K, Kennedy CC, Caples SM, Erwin PJ, Montori VM: Testosterone use in men with sexual dysfunction: a systematic review and meta-analysis of randomized placebo-controlled trials. Mayo Clin Proc 2007, 82:20-28.

90. Tracz MJ, Sideras K, Bolona ER, Haddad RM, Kennedy CC, Uraga MV, Caples SM, Erwin PJ, Montori VM: Testosterone use in men and its effects on bone health. A systematic review and meta-analysis of randomized placebo-controlled trials. J Clin Endocrinol Metab 2006, 91:2011-2016.

91. Kong A, Edmonds P: Testosterone therapy in HIV wasting syndrome: systematic review and meta-analysis. Lancet Infect Dis 2002, 2:692-699.

92. Johns K, Beddall MJ, Corrin RC: Anabolic steroids for the treatment of weight loss in HIV-infected individuals. Cochrane Database Syst Rev 2005, 4:CD005483.

93. D'Agostino RB Sr, Vasan RS, Pencina MJ, Wolf PA, Cobain M, Massaro JM, Kannel WB: General cardiovascular risk profile for use in primary care: the Framingham Heart Study. Circulation 2008, 117:743-753.
94. Menke A, Guallar E, Rohrmann S, Nelson WG, Rifai N, Kanarek N, Feinleib M, Michos ED, Dobs A, Platz EA: Sex steroid hormone concentrations and risk of death in US men. Am J Epidemiol 2010, 171:583-592.

95. Deloukas P, Kanoni S, Willenborg C, Farrall M, Assimes TL, Thompson JR, Ingelsson E, Saleheen D, Erdmann J, Goldstein BA, Stirrups K, Konig IR, Cazier JB, Johansson A, Hall AS, Lee JY, Willer CJ, Chambers JC, Esko T, Folkersen L, Goel A, Grundberg E, Havulinna AS, Ho WK, Hopewell JC, Eriksson N, Kleber ME, Kristiansson K, Lundmark P, Lyytikainen LP, et al: Large-scale association analysis identifies new risk loci for coronary artery disease. Nat Genet 2012, 45:25-33.

96. Wieland LS, Robinson KA, Dickersin K: Understanding why evidence from randomised clinical trials may not be retrieved from Medline: comparison of indexed and non-indexed records. BMJ 2012, 344:d7501. doi:10.1136/bmj.d7501

97. Ferreira ML, Herbert RD, Crowther MJ, Verhagen A, Sutton AJ: When is a further clinical trial justified? BMJ 2012, 345:e5913. doi:10.1136/bmj.d7501.

98. Pereira TV, loannidis JP: Statistically significant meta-analyses of clinical trials have modest credibility and inflated effects. J Clin Epidemiol 2011, 64:1060-1069.

99. LeLorier J, Gregoire G, Benhaddad A, Lapierre J, Derderian F: Discrepancies between meta-analyses and subsequent large randomized, controlled trials. N Engl J Med 1997, 337:536-542.

100. Kenny AM, Bellantonio S, Gruman CA, Acosta RD, Prestwood KM: Effects of transdermal testosterone on cognitive function and health perception in older men with low bioavailable testosterone levels. J Gerontol A Biol Sci Med Sci 2002, 57:M321-M325.

101. Marin P, Oden B, Bjorntorp P: Assimilation and mobilization of triglycerides in subcutaneous abdominal and femoral adipose tissue in vivo in men: effects of androgens. J Clin Endocrinol Metab 1995, 80:239-243.

doi:10.1186/1741-7015-11-108

Cite this article as: Xu et al:: Testosterone therapy and cardiovascular events among men: a systematic review and meta-analysis of placebocontrolled randomized trials. BMC Medicine 2013 11:108.

\section{Submit your next manuscript to BioMed Central and take full advantage of:}

- Convenient online submission

- Thorough peer review

- No space constraints or color figure charges

- Immediate publication on acceptance

- Inclusion in PubMed, CAS, Scopus and Google Scholar

- Research which is freely available for redistribution 